\title{
METHODS OF IMPROVEMENT \\ OF THE MEAT PRODUCTIVITY OF SHEEP
}

\section{Pokhyl Volodymyr ${ }^{1}$ Mykolaychuk Lyudmila ${ }^{2}$}

DOI: https://doi.org/10.30525/978-9934-571-89-3_107

One of the most difficult problems to be solved by the agro-industrial complex in Ukraine is the increase in meat production, in particular beef, pork, chicken, lamb, not forgetting about improving its quality and reducing its cost.

At the same time, one of the important indicators of the welfare of the population is the level of consumption of products of animal origin, especially meat. Today, in many countries of the world, including Ukraine, there is a sharp deficiency of animal

\footnotetext{
${ }^{1}$ Dniprovsky State Agrarian and Economic University, Ukraine

${ }^{2}$ Dniprovsky State Agrarian and Economic University, Ukraine
} 
protein in human nutrition. At a daily rate of total protein for humans $-100 \mathrm{~g}$, including animal origin $60 \mathrm{~g}$, consumption in Europe is satisfied only by $40-70 \%$.

In Ukraine, the level of consumption of animal protein is 2-3 times lower than in developed countries of the world.

To a large extent, this problem is associated with the inappropriate use of available livestock resources, including sheep breeding, taking into account its meat productivity.

To date, the production of lamb in Ukraine and abroad is carried out at the expense of sheep breeding, different productivity directions. Obviously, in the coming years this trend will continue, as the meat industry in the production structure of the economic activity of the sheep industry of Ukraine is still absent. However, as shown by the experience of the states with highly developed livestock, it is necessary to have in the country intensive breeds of sheep meat production direction, as it is one of the reserves to increase the volumes of production of such dietary products as meat of this species.

The research on improvement of meat qualities of sheep of different breeds was conducted by A.M. Zhyryakov and R.S. Hamitsayev [2, p. 38]. They note that the results of crossbreeding of sheep with fine and coarse wool with rams of meat-andwool breeds in various natural and climatic zones indicate a rather high efficiency of using rams both in imported and domestic meat-and-wool breeds.

In many countries of the world, the problem of producing sheep meat is solved by various methods:

- receiving lambs of the first generation from crossbreeding of different breeds, using the effect of heterosis;

- intensive feeding of young sheep;

- breed formation - due to the use of the breeding stock and rams of intensive meat breeds with the subsequent attachment of productive features (breed formation).

The increase in meat productivity of breeds breeding in Ukraine and the near abroad was carried out by crossing such breeds of sheep like Lincoln, RomneyMarsh, as well as Texel, Olibs, Charolais.

The level of meat productivity of sheep and meat production is determined by methodological approaches.

The determining factor in the value of meat productivity and tissue growth, which forms the meatiness of carcasses, is the amount of live weight of sheep, which imprints on some indicators of meat productivity. Therefore, a measure of live weight is an important sign of sheep meatiness. Consequently, when crossing between breeds and breeding to increase the meat productivity of sheep it is necessary first of all to increase the live weight of animals [1, p. 25].

Work on the establishment of sheep's livestock with good meat qualities is also held in Ukraine in the Steppe zone. For this purpose used sheep of such breeds are Askanian meat-wool, Olibs, Charolais, Texel, Gisar (Pokhil V.I).

High productivity and tribal value are shown by Ascanian crossbreds when used in the conditions of the South of Ukraine. Local sheep were characterized by better indicators of growth and development, which made it possible to have a larger live 
weight in the livestock population and higher slaughter quality with good indicators of quality characteristics of meat [5, p. 67].

The results of scientific research and the practice of advanced farms indicate that the main condition for increasing the production of lamb is the good organization of the reproduction of the herd and skillfully developed technology of growing and fattening of the separated lambs. The latter makes it possible to maximize the high growth energy of young animals and switch to the cyclic production of high-quality lamb (Pokhil V.I.).

In general, it should be noted that the most rational way of creating a highly productive livestock of sheep characterized by good meat qualities is to cross the various aboriginal breeds of sheep with rams of intensive meat breeds, breed groups and types, in order to obtain sheep breeds, well adapted to breeding in various natural and economic conditions and that meet the modern requirements of the system of keeping sheep.

At the same time, it is necessary to pay great attention to the cultivation of young stock, as a reserve for the formation of the breeding structure in sheep breeding.

The branch of meat sheep has a number of distinctive features that give it considerable advantages over other:

- sheep are not prone to the conditions of abstinence and feeding. With a minimal cost of cereal concentrates in rations (20-30\%) more efficiently uses cheap pastures, juicy, rough feed waste industry;

- from early spring to late autumn, these animals can use pastures on a special grazing system;

- under favorable conditions of feeding allows relatively quick increase of production of high quality mutton and receive benign sheepskin;

- in these animals, the slaughter yield is $50-60 \%$, the yield of higher grades of meat reaches $60 \%$, and the proportion of valuable parts of meat in the carcass is higher than that of other breeds by $3-6 \%$. The ratio of protein to fat in the carcass is 1.5: 1 or 2: 1 , which corresponds to the modern international requirements of highquality beef;

- in these animals, muscular tissue is better developed on those parts of the body that give the most valuable meat - the back, waist and sacrum areas;

- these animals have a significantly higher index of meatiness and accumulate more fat between the muscles and inside them, which determines the "marbling" of meat, so it has a high energy value (8-12\%);

- meat sheep produce multicomponent products of high quality (meat, sheepskin, blood, bone, internal organs, etc.), each of them is a raw material for many modern productions. Sheep provides the production of good and environmentally friendly raw materials for the leather industry.

One of the breeds used in crossing to increase and improve the meat qualities of sheep in different natural climatic zones is a gisar breed that has its own distinctive features $[3$, p. 8]. 
This breed is breeding in different regions of Ukraine, including the Autonomous Republic of Crimea. In the central zone, which is engaged in the breeding of sheep of this breed, is LLC Terra Rich, Pologovskogo district of the Zaporozhye region.

The Gisar breed of sheep belongs to the group of meat and sebaceous breeds and is one of the largest in the world. The main specialization is the production of meat and sebum. Sheep are characterized by large size, slim build, large live weight, wellmarked meat and fatty forms, well developed, have a strong constitution, strong limbs with well-developed muscles and a strong hoofed horn, which allows you to use high pastures and make long walks in the mountains. They are able to maintain their fatness for a long time under the extreme conditions of winter maintenance and are distinguished by a high capacity for feeding and fattening.

Sheep of this breed have good indicators of live weight of all sex-age groups. The live weight of females at birth at LLC "Terra Rich" is within 4,5-6 kg, rams $5,5-6,5 \mathrm{~kg}$; 4-5-month - 40-45 and 48-50 kg, 18-month-olds - 65-70 and 80-90 kg, adults $-80-85$ and rams $120-140 \mathrm{~kg}$.

The decisive factor ensuring such a manifestation of signs of precocity is the high milk production of the uterus. We have established during the first two months of lactation, gisar's uterus can produce 90-100 1 of milk, the fat content of which varies from 6 to $7 \%$, protein - from 5 to $6.5 \%$.

Average daily gains of live weight of young stock are $280-350 \mathrm{~g}$, with only 6-7 feed units consumed per $1 \mathrm{~kg}$ of growth. This fact reflects the very effective ability of animals to transform feed.

The main task of breeding and breeding work with sheep of Gissar breed is the further increase in their number and consolidation in progeny of high productive qualities, as well as the development of appropriate technology of management, which increases the production of meat - lamb and increase the profitability of the industry.

\section{References:}

1. Bal'mont, V. A. (1968). Ob ispol'zovanii geterozisa v ovtsevodstve. Geterozis v zhivotnovodstve [On the use of heterosis in sheep. Heterosis in animal husbandry]. Moscow: Kolos, pp. 21-37.

2. Zhiryakov, A. M., \& Khamitsaev, R. S. (1986). Promyshlennoe skreshchivanie ovets [Industrial crossing of sheep]. Moscow: Agropromizdat, pp. 37-40.

3. Rakhimov, Sh. T. (1986). Vosproizvoditel'naya sposbnost' matok gissarskoy porody ovets razlichnykh produktivnykh tipov [Reproductive ability of the uterus of the Gissar breed of sheep of various productive types]. Dushanbe: TNIIZh, pp. 7-10.

4. Erokhin, A. I. (1981). Sovershenstvovanie myaso-sherstnykh porod ovets [The improvement of meat and wool sheep]. Moscow: Rosslhozizdat, pp. 8-9.

5. Sukharljov, V. O., \& Derev'janko, O. P. (2003). Vivcharstvo. Navchaljnyj posibnyk [Sheep. Tutorial]. Ukraine: Espada, p. 256. 